\title{
FROM THE MOUTH OF SHADOWS: ON THE SURREALIST USE OF AUTOMATISM
}

\section{Kasper Opstrup}

\begin{abstract}
From surrealism's beginnings around a Parisian séance table, it oscillated between the occult and the political. One of its key methods, automatism, provided access to both the esoteric and the exoteric: it took form in the mid-19 ${ }^{\text {th }}$ century as a spiritualist technique for communicating with the other side while, simultanously, this other side could address political issues as equal rights, de-colonisation and a utopian future with an authority coming from beyond the individual. By tracing the development of automatism, the article shows how automatism in surrealism became a call for both a re-orientation of life and an institutional re-organisation by becoming a divination tool for a future community looking back to hermeticism to find a way forward. The article argues that not only can surrealism fruitfully be understood in the light of an occult revival in reaction to crises but, additionally, that it marks the return of and a reaction to a kind of magical thinking in the modern - due to waning religious and socio-economic orthodoxies - that echoes eerily into our own big data contemporary of social medias where we tend to substitute equations with associations.
\end{abstract}

\section{KEYWORDS}

Surrealism, Automatism, Mystical utopianism, Spiritualism, Alchemy, Radical politics, The imagination, Myth, Hermeticism, Magical thinking, Occult revival, Religion of the future

Let us have no regrets, but let us look, and I am the last person to object to this, let us look gratefully and tenderly at the elemental surfaces in which the world to come has elected to try to make itself apparent. Coffee grounds, molten lead, breath on a mirror still provide those inscrutably clear veils dear to young woman. ${ }^{1}$

\section{MARGIN WALKERS IN THE BORDERLAND}

Monday, 25 September, 1922.

9pm. A room with dimmed lights.

42 Rue Fontaine in Paris's ninth arondissement, the Pigalle district. 
André Breton, a young poet who soon is to become the main theoretician of French surrealism, sits down around his dinner table, joining hands with comrades René Crevel, Max Morise, Robert Desnos and Simone Breton.

Inspired by Crevel's summer meeting with a spiritist medium, Madame M., they were about to experiment with the form of the spiritualist séance in order to call forth trance states, gnostic insights into how to liberate the unconscious. The aim was to receive "magic dictations" from "the echoes of universal consciousness," as Breton would write in his chronicle of the event, "The Mediums Enter." 2 This inwards turn towards the occult realms of the unconscious would be a gateway to a new real that was to be 'surreal;' a category which - according to Louis Aragon - would reconcile the experience of reality with those of chance, dreams and the fantastic. ${ }^{3}$ In the wake of World War I, intense experiences at the edge of consciousness should be explored and mapped in order to discover and retrieve new feelings, adequate for tomorrow.

Two days later a second session was held.

The initial group was now joined by Max Ernst, Benjamin Péret as well as Paul and Gala Éluard. Throughout the following six months most of Parisian Dada passed through the sessions.

In order to question the nature of freedom, the nascent surrealist movement took a decidedly turn towards psychic experimentation and spiritualist techniques explored in a collective context. Automatism in all its variants would become a key method to explore the unknown vistas of inner space, and the séances would be the keystone transforming Paris dada into surrealism through what in surrealist lore has become known as l'époque des sommeils - the period of sleeping fits.

This period extended from September 1922 until February 1923 when the participants decided to put an end to the séances, frightened by the possible consequences of their exploration of unstable mental states: Crevel tried to persuade those under hypnosis to hang themselves from coat hangers in a darkened room, Desnos chased Éluard into a garden with a kitchen knife. ${ }^{4}$

During the sleeping fits what would officially be known as surrealism with Breton's 1924 manifesto adapted aspects of popular occultism for creative experimentation, thus making precedence for the myriad of occultural pranksters following their lead throughout the $20^{\text {th }}$ century. Dada's rejection of literature had led to a nihilistic impasse. Especially Breton and Éluard were searching 
for an egress without returning to "literature" or "self-expression." Automatism seemed to offer this. Some of the works that grew out of the experiments include Breton's Soluble Fish (1924), Robert Desnos’ Mourning for Mourning (1924) and Liberty or Love! (1927), as well as many of the texts collected in Benjamin Péret's Leg for Lamb (first published 1957).

What does this turn towards the occult signify? How can it be understood in relation to not only surrealist cultural production but also their accompanying political project? Surrealism had (and has) both an esoteric and an exoteric side. It called for a new marvellous myth that evolved from a loosely defined communism in the late 1920s where the Parisian group for a period aligned itself with Marxism and the Communist Party to the more occulted anarchist stand of the 1950s. All along, it was drawing on a wide range of sources and predecessors spanning the spectrum from political prophecy and poetic language to alchemy and voodoo. ${ }^{5}$ In order to unfold some of these ambiguities, I will focus on one of surrealism's key methods: automatism. What constitutes the automatic message, what is its pre-history and what is its limits?

In order to come to terms with Breton's call in his second manifesto of 1930 for the "occultation" of surrealism, claiming that the movement shared goals with the alchemists of yore, and his referral to key esoteric figures such as Abramelin the Mage and Eliphas Levi in the same breath as to Hegel and Marx - the surrealist revolution was not to be only communist, it was to be magical and sexual - I follow the Scottish art historian Nadia Choucha's argument: surrealism is a twentieth-century development of a nineteenth-century tradition in art and poetry, and was heavily indebted to the occult revival of that period. 6

In its attempt to simultaneously re-orient life and reorganise society, surrealism combined both religious and political forces, since any revolution in human affairs must, as already Tocqueville observed, be both religious and political. It must be a project of world transformation that entails both a change in consciousness and a change in institutions. Historical precedents can be found among, for example, medieval heretical movements like the Anabaptists or the Brethren of the Free Spirit but the most important predecessor in this context may be found at the beginning of the modern occult revival with the American Spiritualist Movement, inaugurated by the Fox sisters, March 1848, in Hydesville, New York, from where it rapidly spread to France, Britain and beyond. ${ }^{7}$ Spiritualism allied itself with emergent causes such as women's suffrage, the abolition 
of slavery as well as later de-colonisation, and, in Catalonia, for example, spiritist-anarchist groups proliferated from the 1860 s to the 1930s, challenging traditional power structures and labour relations. ${ }^{8}$

For this reason I will pay attention to the development of automatism in, especially, spiritualism and turn of the century occultism in order to understand its role in surrealism which, in this perspective, is linked more to the romantic/symbolist lineage and not as much to dada and the other modernist avant-garde movements.

Equally to many other new social and religious movements with a leaning towards the aesthetic, it can be argued that the new myth sought by surrealism - a myth to unite us all in the absence of myth - is a call for a kind of secular religion of the future, often immanent, acephalous, non-transcendent, and often inspired by the prisca theologia of Hermeticism and its "religion of the mind." 9 It is a call for social, political and cultural revolution that originates in the inner self of the individual and echoes across the $20^{\text {th }}$ century into our contemporary. After examining the prehistory of automatism, I will briefly turn to how the surrealist aims and methods are related to Hermeticism and alchemy, how they were looking back in order to go forward, before I will end on a brief discussion of some of the implications of the revival of magical thinking in both the arts and contemporary society at large.

Occultism reappears in times of crises and precarity - or, as the esoteric scholar Nicholas Goodrich-Clarke puts it: "It is notable that esoteric ideas often attend the breakdown of settled religious orthodoxies and socioeconomic orders" - just like spiritualism and mediumism usually flower in the wake of catastrophes, war, disease, when many grieve their lost ones. ${ }^{10}$ It addresses certain questions related to modernism in general and can be viewed as a re-writing of the past in order to divinate an alternative future.11 Just like Renaissance scholars such as Masilio Ficino and Pico della Mirandola turned towards Hermeticism and the Greco-Roman past in order to rejuvenate their contemporary, the surrealists turned towards the alchemical revival of the Renaissance. The resurgence of the occult is thus linked to a new distribution of heterodox perspectives in response to the waning hold of orthodoxy.

Breton was careful to emphasise that surrealism was not "fideistic" in its use of esoteric material. Rather, it was a concern with esotericism's potential to provide a fuller form of knowledge based on analogies and correspondences that could restore a "key with 
which to decipher the world." 12 None of the artists and writers I am concerned with became devout followers of any kind of religiosity and their engagement with esoteric ideas was just as likely to veer off into playful satire as to explore esoteric themes as alternative forms of knowledge. It was an understanding of esotericism as a point where artistic, scientific and spiritual knowledge converge and where the engagement with occult ideas on the one hand was a form of thinking and, on the other, an experience of transmutation.

Nadia Choucha argues that esoteric ideas always have held an attraction for the avant-garde in their opposition and challenge to the establishment and accepted values due to that it is considered alien to "mainstream" thought. ${ }^{13}$ This is also why the occult was allied to revolutionary and subversive politics in France. Because it traditionally is veiled in a certain amount of obscurity and ambiguity - the literal meaning of the word "occult" is "hidden" - it becomes an attractive system to artists and poets due to that it can be interpreted and applied according to individual desires.

October 1924 saw the fully-fledged surrealist movement come into existence. During this month both Breton's "First Surrealist Manifesto" and Louis Aragon's "A Wave of Dreams” were published, and the Bureau of Surrealist Research - later to be directed by Antonin Artaud - opened its doors at 15 Rue de Grenelle.

In his first manifesto, Breton credited the birth of surrealism to a hypnagogic experience. This produced a fascination of the threshold between being awake and various altered states: dreams, trances, sleep, psychosis, hypnosis and so forth. The focus on sleep, dreams and the unconscious was seen as a portal to a dream realm, that other world in the mirror beyond the threshold of consciousness. In the aftermath of the first heroic period of surrealism, Breton $(1932,139)$ wrote that the connection between the two different states - the esoteric and the exoteric, inner and outer reality - requires the "constant interpenetration of the activity of waking and that of sleeping." 14

The surrealists wanted to mingle the conscious with the unconscious, the possible with the impossible. ${ }^{15}$ In his first manifesto, Breton famously defined surrealism as "psychic automatism," an expression of the actual functioning of thought. ${ }^{16}$ Aragon elaborated the meaning of the surreal:

Having weighed up its experiences of Reality - in which it indiscriminately mixes everything that exists - the mind naturally juxtaposes what it knows of the Unreal. Only when the mind has 
gone beyond these two notions can it begin to envisage a wider experience, one where these other two experiences co-exist, and that is the Surreal. Surreality, the state where these concepts are fused by the mind, is the shared horizon of religion, magic, poetry, dreaming, madness, intoxication and this fluttering honeysuckle, puny little life, that you believe capable of colonizing the heavens for us. ${ }^{17}$

Like many surrealist methods to circumvent consciousness automatism - pioneered within what would become surrealism by Breton and Philippe Soupault in 1920 with the collaborative effort The Magnetic Fields - is an aleatory technique based on unpremeditated free associations where one writes as fast as possible without thinking about what is appearing beneath the pen. The unexpected material produced can then be used either as the basis for further composition or left without revision. ${ }^{18}$

Even though Breton would go on to call the experiments a "continuous misfortune" in “The Automatic Message” (1933), he continued, along with other surrealists like the painter Max Ernst, to rely on the method in one way or the other for the rest of his life. The painter Adrian Dax, somewhat echoing Breton's statement of two decades earlier, stated in 1950 that even though the activities with mechanical automatism revealed a long sequence of failures along with some successes, they, nonetheless, taken as the bases of an imminent experimentation, are able to "engage us on a path along which one should expect to advance only over ruins." 19

The term "automatic writing" is most often associated with the surrealists, but they did not invent it. The main root of automatism is to be found in spiritualism, which can be seen as the starting point of the modern occult revival. ${ }^{20}$ It made its way into surrealism via the dynamic psychiatry of Pierre Janet - one of the founding fathers of psychology alongside William James - and his doctoral thesis, De l'Automatisme Psychologique (1889), which Breton and Philippe Soupault were avidly reading in 1919 before they began work on The Magnetic Fields. ${ }^{21}$

For Janet, automatic writing was capable of bridging the gap between two layers of consciousness, the subliminal and the supraliminal mind, roughly corresponding to a conscious and an unconscious state. This hugely influenced the surrealist concept of automatic writing. What enabled Janet to develop clinical tools for the treatment of hysteric patients was a sort of scientific reappropriation of spiritualist possession. The British cultural historian Alex Owen writes: 
Like Freud, whose secularized occultism transformed demon possession into neuroses, spirits into ego introjects, and exorcism into psychoanalysis, Janet's work made use of essentially occult methodologies - automatic writing, trance, and the discourse of possession - for the purposes of bringing the occult into the clinic and under control. ${ }^{22}$

Automatism permitted radical speech and transgressive behaviour because it was seen as originating from a spiritually elevated "elsewhere," not from the "flawed feminine body of the Spiritualist herself." 23 As Francis McKee phrases it, it was "activism without a verifiable activist." ${ }^{24}$ Whether the spirits were real or not, they made it possible for people who did not have a voice suddenly to have one. It is radical politics entering the public discourse as supernatural possession, not unlike the revolutionary rhetoric spouted by Robert Desnos during the period of sleeping fits where the attendants saw automatism as a radically democratic way of writing and painting. It should do away with the cult of the genius to make way for "a poetry made by all" as Comte de Lautréamont famously quipped in his preface to a future book left unwritten by his death, Poésies (1870).

Interestingly, keeping in mind that Breton in the second manifesto states that the surrealists are seeking a supreme point that is able to unify all opposites, a veiled reference to the kether sephira from the Jewish Kabbala - the plane of pure spirit which many magical orders have as the ultimate goal for self-development - the French philosopher Georges Bataille wrote a short essay on surrealism for the journal Combat in 1948. In this he concluded that through this state of mind that reaches for unification "an existence beyond the self is experienced as a spiritual authority in whose name it is possible to speak." 25 To ground such a loaded term as the "spiritual" he emphasised that by "spiritual" he merely meant "beyond the individual." Contrary to Jewish mysticism and ceremonial magic, though, in reaching for that supreme point beyond the individual, the surrealists did not seek unification with God, but with the social.

\section{THE SPIRITUALIST ROOTS OF AUTOMATISM}

The main constituents of spiritualism were Mesmerism, a predecessor to hypnotism, and the branch of German Romanticism called Naturphilosophie. The French followers of Franz Anton Mesmer neglected the medical applications of Mesmerism and, instead, while combining it with ideas of social emancipation, 
humanitarianism, and radical social reform, they explored the esoteric implications of induced somnambulism and deep trance states. "Animal magnetism" was perceived to restore the unity between conscious life and unconscious activity and the trances were thought to not only confer powers of prophecy and clairvoyance, but also produce visions and automatic writings written by the "magnetised" subjects. An example of this are the divine writings received in 1785 by Marie-Louise de Monspey from the spirit of the Virgin Mary. ${ }^{26}$

In 1829, the German poet and nature philosopher Justinus Kerner published his account of the Seeress of Prévorst, Friederikke Hauffe, that became famous throughout Europe, and knowledge of Kerner's work (translated into English in 1845) would eventually link spiritualism with Mesmerism and esotericism. Esotericism can in this light be seen as a system of rejected or hidden knowledge which in combination with an experimental and revolutionary politics was attractive for the ones who desired to live another way or flat out rejected the world as it was.

Spiritualism itself was a product of mass society and the disenchanted world of secular modernity: it could both fulfil a religious function and, at the same time, enjoy a close dialogue with positivist science, along the way giving rise to, for example, the Society of Psychical Research (SPR) in London where the phenomena were to be recorded and tested by modern equipment. The SPR was co-founded in 1884 and for a period had Frederic W. H. Myers - praised by Breton for his "gothic psychiatry" in "The Automatic Message" and author of Human Personality and Its Survival of Bodily Death (1903) that would have a tremendous impact on the surrealists with its speculations on the unconscious - as its president.

The historian of modern occultism James Webb argued that the esoteric strain of knowledge, based on gnosis instead of episteme, and its "flight from reason" can be regarded as the heresy of irrationalism in the post-Enlightenment era, where the strategy of epistemological exclusion is comparable to the heresiological labels the Church used to disqualify esoteric dissent. ${ }^{27}$ Modern occultism following spiritualism such as the Theosophical Society or the Hermetic Order of the Golden Dawn can to a certain extent be seen as an alternative type of psychology of self-realisation, seeking to unite what has been separated.

To begin with, automatism took the form of automatic writings, often written collectively by a circle who would place their hands on a planchette. In the early days of spiritualism, the planchette 
would be equipped with a pen, thus producing writings or drawings, while from the 1880s onwards with the popularity of ouija-boards, the hole in the planchette would be left empty and used to identify letters and numbers instead. Automatic drawings also soon became popular, showing that one of the roots of abstraction can be found in esotericism with painters like Georgiana Houghton and Hilma of Klint who predated Kandinsky with up to 60 years. Houghton tried to portray the afterlife and the kingdom of God through the use of an idiosyncratic colour symbolism produced in trances and combined with dictations from the deceased she was channeling, Titian among others, thus expressing sacred knowledge through abstraction. ${ }^{28}$

There is a whole literary genre of "revealed" or channeled scriptures hiding in the shadows of the occult. As we saw above, the Virgin Mary could write through mesmerised subjects but also Andrew Jackson Davis, the so-called "Poughkeepsie Seer," communicated with a spirit he later identified as Swedenborg and went on to publish The Principles of Nature (1847). This established itself as a founding text of modern spiritualism and anticipated such automated classics from modern esoteric movements as Blavatsky's Isis Unveiled (1877), Levi's Aquarian Gospel of Jesus Christ (1908), and Jane Roberts's Seth Material (1970), not to mention Aleister Crowley's The Book of the Law (1904) or William Butler Yeats's A Vision (1925).

Spiritualism formalised the creative techniques of automatism, facilitating radical experimentation if not artistic quality. This was interpreted positively by early psychologists of the unconscious, such as Myers and Théodore Flournoy, who thought it was the subliminal self speaking through the artists, an interpretation later shared by the surrealists. ${ }^{29}$ The new framework was wholly secular and based on psychoanalysis, but the techniques were fundamentally occult.

From its roots in pre-revolutionary French Mesmerism and spiritualism - from which the vision of the happy departed dwelling in 'Summerland' helped promote a belief in utopian social experiments and millenarian visions of the political future - automatism reared its head again in the dynamic psychiatry of the 1880s with names like Janet, Myers, and Flournoy's seminal From India to Mars (1899), a book canonised by the surrealists due to its descriptions of the Martian spirit visions of the medium Hélène Smith - ultimately judged to be a case of cryptomnesia - as well as in fin-de-siécle occultism. Where the former mostly relayed on 
hypnosis and the diagnosis of hysteria, the latter provided a whole arsenal of tools from planchettes to ouija-boards that should ease communication with the other side, be it the dead, extra-terrestrial intelligences and holy guardian angels, or the unconscious. The most significant order at this time - seminal in creating a direction for $20^{\text {th }}$-century occultism - was the Hermetic Order of the Golden Dawn, led by Samuel Liddell MacGregor Mathers and counting people like Yeats, Crowley, Annie Hornemann and Arthur Machen among its initiates.

\section{AUTOMATISM IN THE EARLY $20^{\text {TH }}$ CENTURY}

Next to Crowley, the British painter Austin Osman Spare might have been the most influential occultist seen from the late $20^{\text {th }}$ and early $21^{\text {st }}$ centuries. Spare was briefly involved as a probationer in Crowley's magical order, the Argentum Astrum - formed in 1909 after the collapse around the year 1900 of the Macgregor Mathersled Golden Dawn which it was based upon - but developed his own personal system of "sigil magic," the Zos Kia Cultus, in his modern grimoire The Book of Pleasure: The Psychology of Ecstasy from 1913. 30

Spare can - even though the surrealists seemingly did not know his work - be seen as a British precursor of surrealism who, inspired by William Blake, the Pre-Raphaelites, and Aubrey Beardsley, experimented with automatic drawings as early as c. 1900. In the self-edited journal Form, Vol 1, no 1 (1916) he wrote that:

[t]he objective understanding, as we see, has to be attacked by the artists and a subconscious method, for correction of conscious visual accuracy, must be used. [...] The mental mechanisms used [in automatic drawing] are those common in dreams, which create quick perceptions of relations in the unexpected, as wit, and psycho-neurotic symptoms. [...] This means of vital expression releases the fundamental static truths which are repressed by education and customary habit and lie dormant in the mind.

The impetus for automatic drawing is often a type of pareidolia, the tendency of the brain to create a pattern where no pattern exists. The technique is well-known from Leonardo da Vinci, Victor Hugo, and Alexander Cozens, as well as from psychoanalysis in the form of the Rorschach test. It is thought to evoke images from the unconscious, since there has been no intervention in the creation of the initial pattern. 
In surrealism, the practical development of pareidolia into painting was later on credited to Oscar Dominguez who "pioneered" it in 1937 under the name of decalcomania where paint was pressed between layers of paper, leaving a random pattern then to be interpreted and worked into an image as in, for example, the landscape surrounding Loplop and the woman (supposedly representing Leonora Carrington) in Max Ernst's painting Europe After the Rain (1941). In general, Ernst deployed aleatory techniques such as grattage, frottage, and decalcomania in the paintings that did not rely on collage techniques as a sort of semi-automatism where the random produced patterns could be used for artistic elaboration. In essence, pareidolia is intimately connected to a sort of magical thinking: the brain handles complexity by pattern recognition.

Spare sought sexual and psychological liberation. ${ }^{31}$ Contrary to Crowley, who, when he received The Book of the Law by dictation in 1904, thought he was communicating with an extraterrestrial being, Aiwass, who he later identified as his Holy Guardian Angel, Spare, like the surrealists, saw automatism as a way of communicating with the unconscious. Immanence instead of transcendence. But unlike the surrealists who thought of automatism as a way of eliminating genius, to Spare consciousness itself was an illusion and it was the condition of Genius when "the mind is illuminated by sub-conscious activity." 32 Automatism was beneficial to the trained artists, not something that would turn us all into artists, a quite more individualist-elitist project than the surrealist attempt at making the unconscious conscious with the ultimate aim of universal emancipation for all.

Automatism in surrealism thus drew upon a plethora of esoteric influences, which the surrealists were fully aware of: "With a shudder, we cross what the occultists call dangerous territory. "33 Breton goes to great length to explain that he is not interested in automatism to communicate with the dead. Instead, by liberating the unconscious, they wanted to fuel a myth about the emancipation of man. As Breton noted on the political position of surrealism: “' $[\mathrm{t}]$ ransform the world,' Marx said; 'change life,' Rimbaud said. These two watchwords are one for us.” 34

One of the key benefits of automatic writing is that it depersonalises the work produced. Even though it might not have much of a literary value, it still has no author. At the same time, as Bataille also points out, it can be understood as a break with the material world of logic and reason. Through delirious, ecstatic insights 
it wants to forge a link to the primitive, a mode of existence that is perceived to have been lost in a quest to explore all that can be explored by wo/man and reconstitute what was fundamental before human nature was enslaved by technical work, aligning it to the Marxist critique of all forms of subjective and social alienation and of separation. Bataille writes:

What essentially characterizes automatic writing [...] is that it is an act of rupture [...] with an enslavement which, beginning with the world of technical activity, is determined in words themselves, to the extent that these words participate in the profane world or the prosaic world. Someone who sits comfortably, forgetting to the greatest degree what exists so as to write at random on a blank sheet the most vibrant delirium which passes through his mind, may end up with nothing of literary value. $\mathrm{He}$ knows that this is of no importance; he has experienced a possibility which represents an unconditional rupture with the world in which we act to feed ourselves, in which we act to cover and shelter ourselves. He has essentially undertaken an act of insubordination, in one sense he has performed a sovereign act. At the same time, he has accomplished what, within the meaning of religion itself, could appear predominant: he has achieved the destruction of the personality itself. 35

Not only is it a depersonalisation of the author-subject, but it is also a collective form of writing as is the case with the oujia-board: a circle of people each place a finger on the planchette before it begins to communicate with the other side. Some of Breton's key automatic texts were collaborative efforts with Soupault and Élouard. One of the most used techniques for producing collective, automatic writings were aleatory chain games like, for example, "the exquisite corpse" where each participant adds a word or a sentence either by following pre-established rules like that an adjective must be followed by a verb to be followed by a noun and so forth or by being allowed to see only the end of what the previous person contributed.

\section{LOOKING BACK WHILE GOING FORWARD}

The interest in surrealism for exploring numinous and liminal states of mind was intrinsically linked to their conception of society around them. The transformation of the internal world through poetry and love corresponded with the revolutionary social transformation of the external world through the power of the imagination. 
Breton wrote in his "Prolegomena to a Third Manifesto or Not" about a new myth, not unlike George Sorel's social myth which was images meant to inspire and inflame in the here and now, and asked "in what measure can we choose and adapt, and impose, a myth fostering the society that we judge to be desirable?"36 This myth should be the origin myth of new patterns of behaviour and new social arrangements. It would not be the personal myth of an artist but collective myths able to emancipate wo/man. Art should be a rediscovery of the originality it once had in a society that is on the threshold of a new society, not based exclusively on the instruments of reason. It would be myths to challenge and change the world, making us all into prophets and visionaries along the way by enabling us automatic access to the unconscious and, thus, something that exceeds who and what we are and sets us on a mutable path of human becoming.

If the ends are the universal emancipation of wo/man and the means are myth and automatism, then where do we begin? Aragon states this quite clearly: "Liberty begins where the marvellous is born." 37

The marvellous is one of the central concepts of surrealism. The ways into the realms of the marvellous, due to the tension they produce, are magical ceremonies, ecstatic states, simulating morbid attitudes as well as "the freedom of mental automatism." 38 The rejection of deliberate control, the wish to let go of conventional ties and the systematic use of dreams and automatic writing have reopened the sources of the marvellous. The only thing it requires is "the revolutionary will to escape mediocrity, to assert the laws of desire over the laws of the universe" which comes quite close to the modern definition of magic and practical occultism as it has developed since Crowley. ${ }^{39}$ In the introduction to his Magick in Theory and Practice, he famously defined what he called 'magick' - spelled with a $\mathrm{k}$ to differentiate it from illusionism - as "the art and science of causing change to occur in conformity to the will" with the addendum that it happens according to natural laws so that the change is something of which the object is "capable by nature." 40

While the marvellous is an example of the occultation of surrealism and signifies the surrealist conception of beauty as something shattering and convulsive, it also has broader implications since it describes the central surrealist experience of reality as something more than meets the eye. The marvellous, in other words, pertains to surrealism's attempts to dissolve the definite borders between reality and the imagination, and detect correspondences that are obscured by rationalist thinking. As Mabille writes, it finds it origins 
in the eternal conflict that pits our heart's desire against our means for satisfying them and grows out of uneasiness and the desire to "lift the veil of mystery." 41

That surrealism sought a new truth through mysteries and the hermetic tradition unveiled itself in one of the central images of surrealism: that of "communicating vessels." Breton unfolds this in his book by the same name from 1933 where he sees the communicating vessels as representing interior vision and exterior fact. The surreal is always passing back and forth between two modes and the meeting itself is of vital importance, it is the communicative space of the sacred in Bataille's thought, since it is a place for revelation through the material juxtaposition of heterogeneous elements - surrealist combinations symbolising conscious and unconscious liberation initiated by (mad) love - creating a work where no one has the perception of being the author and which is purely immanent.

The communicating vessels are indebted to the hermetic adage of "as above, so below," the belief that there are correspondences and a constant exchange between the exterior and interior world. They are the alembic vessels of alchemy in which to produce the philosopher's stone, which is to say that they are ourselves.

As so often with the occult, the symbolism is multivalent, but the message is hard to miss.

This constant meeting and interaction between two states is re-occurring in surrealists texts as, for example, Leonora Carrington's journey through madness, Down Below, where she describes this fundamental surreal encounter in the following words: "[t]he egg is the macrocosm and the microcosm ... the task of the right eye is to peer into the telescope, while the left eye peers into the microscope." 42

As one of the central alchemical symbols, the egg stands for the alembic vessel in which the work takes place. Carrington combines the egg with the figure of the union of microscope and telescope to fuse her reliance on alchemy with an expression of her insight into the need to take both the great and the small into account, to see them as complementary and interdependent phenomena rather than be overwhelmed by either self or world. This dual focus and its attendant reconciliation of opposites can again be seen as an allusion to Hermeticism and its goal of creating the alchemical androgyne. 
By extension, surrealism can be seen to be influenced by the central tenet of alchemy, "solve et coagula," dissolve and coagulate, where the alchemist analyses and breaks down prime matter to two fundamental opposites, masculine (philosophical sulphur) and feminine (philosophical mercury), before synthesising them together in a more perfect way to create the philosopher's stone. This makes, for example, the collage into a fundamental alchemic operation. The process takes place in the aforementioned alembic vessel, which is heated by the use of an athanor, an alchemical oven. As shown by the well-known alchemical anagram V.I.T.R.I.O.L and as it is also conspicuous from Jungian psychoanalysis - this alembic vessel was often thought to be wo/man so that the transformation would be an inner transmutation to a higher level of consciousness: Visita Interiora Terrea Rectificandoque Invenies Occultum Lapidem - visit the inner earth and by rectifying it you will find the hidden stone.

The goal of alchemy is not to gain access to another world beyond the individual; it is about perfecting what is already there through a process of analysing and re-assembling. The emphasis in surrealism thus gradually shifted from experimentation with the releases of unconscious material to a call to consciously transform reality through unconscious inspiration. They wanted to create a new myth on which to create a new tomorrow and, ultimately, produce a new type of wo/man. Magical cultures have always been exercises in "fictioning," mythopoetic tangents that produce new beliefs from arcane sources. This does not mean that they are any less real or functional.

Through the focus on myth and transmutation, surrealism obtains a cultic socio-religious dimension, looking back in time to go forward in history towards a community brought together by a surrealist religion of the future enabling us to evolve and become more than what we are through emancipating the unconscious.

\section{THE RETURN OF MAGICAL THINKING}

For the surrealists, revolutionary change became a project for the imagination, our capacity for generating new myths which would arguably enter the territory of searching for a more tolerant and non-dogmatic - as well as non-transcendent - religion based on Hermeticism and characterised by its will to find correspondences between a microcosm and a macrocosm, an inner and an outer state that will produce a third, synthetic state.

The search was thus centred on the meeting and communication between two different states, the communicating vessels, as well 
as going beyond the individual in a way that transforms the individual. It is a promise of an experience of transmutation where we will be changed, evolve to become more than what we are, become alien, post-human, and thereby overcome alienation. These ideas can fruitfully be compared to the concepts of the religious and the spiritual in the thinking of Bataille. ${ }^{43}$

Already with spiritualism, theosophy and before, there was a dream that magic, Hermeticism, and the occult could become a religion - understood in its etymological sense of that which binds together - of the future. This idea reappeared not only with surrealism but also on a broader scale with the counter-cultures of the 1960s and has re-appeared in our current time of crises, that it might be necessary to go backwards in order to go forwards, that the past might rejuvenate a future fueled by imaginative myths. The imagination takes centre stage based on the presupposition that change is dependent on crisis since the mark of the imagination is that it is able to do the work of crises without crisis.

Any real change begins in dreams.

This ties in with the idea that we are on the brink of evolving and become something more than we already are and that in this lies the hidden stone to build a new type of community upon. Whether we are becoming superhumans, cyborgs or bodies of light, the idea was widespread in the early to mid-20 $0^{\text {th }}$ century where it can be found not only among the surrealists but also from, for example, Monte Verité and the German Lebensreform to the myriad of free universities and experimental communities appearing throughout the 1960s and 1970s.

The futuristic dimension of this way of thinking finds an expression in what has become a science fiction adage known as Clarke's third law, originally formulated in Arthur C. Clarke's 1973 essay "Hazards of Prophecy: The Failure of the Imagination": "Any sufficiently advanced technology is indistinguishable from magic." This rings eerily into our contemporary where annihilation has become a psychological substitute for the millennium and big data has occulted society by forcing a new kind of algorithm-based magical thinking upon us which hides it machinations behind an unpenetrable veil.

When Google, Facebook and our technocratic overlords are customising advertising or proposing possible destinations to us while we navigate the internet it is based upon that the algorithms recognises our digital behaviour based on similarity to a peer group instead of causality. If our friends like it, the algorithms 
believe that we might like it too. Due to the complexity of the algorithms and abstract mathematics, the black box of the laptop, we tend to internalise this way of navigating ourselves, in the process leaving Enlightenment thinking, based on rationality and causality, behind in order to navigate the easy exchange of images in a world of proliferating screens where the images circumvent linear logic by substituting associations for equations and collapsing difference into unity.

In a contemporary post-factual world of image politics, action has become magical interventions into reality in a realm of fantasy.

This constitutes a return to magical thinking since associations exists between seemingly unconnected subjects or object, or like Stephen Duncombe has pointed out: “You don't have to believe, as meteorologist Edward Lorenz first put it, that the flutter of a butterfly's wings in Beijing could create a tornado in Texas to acknowledge that we are wired into a complex ecological and social system with lines of connection and association that are not immediately apparent." 44

While the occult revival is linked to crises and catastrophe, the return of magical thinking is thus connected to that linear logic belongs to the age of the sentence while associative logic is in tune with the present visual era, or, as the German philosopher Theodor Adorno puts it in his third thesis against occultism, by regressing to magic under late capitalism, thought is assimilating to late capitalist forms. ${ }^{45}$ Where this for Adorno resembled totalitarian terror - which he saw as merged with the occult, dismissing the latter as "subjectivity mistaken for its object" - it might be possible today to see the occult as more than a case of narcissistic projection of one's own ego-ideal with which s/he then identifies. ${ }^{46}$ On the contrary, as Larsen and Pasi argues, it might be that "the aesthetic, experiential and political ambiguities of the occult make it an apt vocabulary for questioning the categories through which we see the world." 47 To Larsen and Pasi, the occult describes a withdrawal from the regime of visual identification which, as we have seen above, forces us to navigate our big data environment by similarity instead of causality, along the way transforming knowledge to a matter of gnosis instead of episteme.

That the magical thinking of Breton and the surrealists and their attempts to guide invisible forces to set change in motion followed this latter line of argumentation is obvious in that Breton in both his first manifesto and in his essay on "Lautréamont" from The Lost Steps, argues in favour of language and causality, for "that which follow from one another" and against synchronicity and the image 
but with a kind of mental jiu-jitsu that uses the force of the latter against itself. ${ }^{48}$ Creating the philosopher's stone was the equivalent to liberate the mind and let loose the imagination but not as escapism. The occult aesthetics becomes an egress from the image politics of power by carrying a utopian hope, that through the experience of transmutation there is another path to an unknown future created by correspondences between the micro and the macro, inner and outer, representation and reality, where wo/men still have a free will to choose their own destiny and become a new type of collective individual.

Reservoirs of darkness can never be dispersed.

\section{NOTES}

1 André Breton, "The Automatic Message," in: The Automatic Message - The Magnetic Fields - The Immaculate Conception, by André Breton, Paul Élouard and Philippe Soupault, trans. A. Melville (London: Atlas Press, 1997), 14. The work presented here is supported by the Novo Nordisk Foundation, NNF160C0019684.

2 André Breton, "The Mediums Enter," in: The Lost Steps, by André Breton, trans. Mark Polizzotti (Lincoln: University of Nebraska Press, 2008), 91.

3 Louis Aragon, "A Wave of Dreams," trans. Susan de Muth, Papers of Surrealism 1: 1-12.

4 Terry Hale, Introduction to Liberty or Love! and Mourning for Mourning, by Robert Desnos, trans. Terry Hale (London: Atlas Press, 2012), 13.

5 See, for example, Patrick Lepetit, The Esoteric Secrets of Surrealism - Origins, Magic, and Secret Societies, trans. J. E. Graham (Rochester: Inner Traditions, 2014).

6 Nadia Choucha, Surrealism and the Occult: Shamanism, Magic, Alchemy, and the Birth of an Artistic Movement (Oxford: Mandrake Press, 2010), 126.

7 See, for example, Ann Braude, Radical Spiritis: Spiritualism \& Women's Rights in Nineteenth-Century America (Bloomington: Indiana University Press, 2008), or Alex Owen, The Place of Enchantment: British Occultism and the Culture of the Modern (Chicago: The University of Chicago Press, 2007).

8 Francis McKee, Even the Dead Rise Up (London: Book Works, 2017), 117.

9 See, for example, Gary Lachman, The Quest for Hermes Trismegistus: From Ancient Egypt to the Modern World (Edinburgh: Floris Books, 2016).

10 Nicholas Goodrich-Clarke, The Western Esoteric Tradition: A Historical Introduction (Oxford: Oxford University Press, 2008), 13.

11 See, for example, Owen, Enchantment, as well as Corinna Treitel, A Science for the Soul: Occultism and the Genesis of the German Modern (Baltimore: The John Hopkins University Press, 2004), and Leigh Wilson, Modernism and Magic: Experiments with Spiritualism, Theosophy and the Occult (Edinburgh: Edinburgh University Press, 2012).
12 André Breton, Conversations: The Autobiography of Surrealism, trans. M. Polizzotti (New York: Paragon House, 1993), 229.

13 Choucha, Surrealism, 126.

14 André Breton, Communicating Vessels, trans. M. A. Caws and G. T. Harris (Lincoln: University of Nebraska Press 1990), 139.

15 Breton, Vessels, 26.

16 André Breton, "Manifesto of Surrealism," in Manifestoes of Surrealism, by André Breton, trans. R. Seaver and H. R. Lane (Ann Arbor: University of Michigan Press, 2010), 26.

17 Aragon, Wave, 5.

18 For examples on the range of automatic writings as well as other text-generating "chain games" (in that they were most often collective enterprises), see Alastair Brotchi and Mel Gooding, A Book of Surrealist Games, (London: Shambala Redstone Editions, 1995), 17-42.

19 Adrian Dax, "Automatic Perspective," in The Surrealism Reader - An Anthology of Ideas, ed. Dawn Ades, Michael Richardson and Krzysztof Fijalkowski (London: Tate Publishing, 2015), 308.

20 For a history of Western esotericism and, especially, its development since the Renaissance's hermetic revival, see Goodrich-Clarke, Western. A short summary of the tradition appears in Goodrich-Clarke, Western, 3: "The Western esoteric traditions have their roots in a religious way of thinking, which reaches back to Gnosticism, Hermeticism, and Neoplatonismen in the Hellenistic world during the first centuries A.D. In the Renaissance, the rediscovery of ancient texts led to the scholarly revival of magic, astrology, alchemy, and Kabbalah. Following the Reformation, this spiritual current gave rise to theosophy, Rocicruciansim, and Freemasonry, and the modern occult revival extends from nineteenth-century spiritualism, $\mathrm{H}$. P. Blavatsky's Theosophy, and ceremonial magical orders to twentieth-century esotericists such as Rudolf Steiner, Alice A. Bailey, and George Ivanovitch Gurdjieff, and the analytical psychology of Carl Gustav Jung."

21 Tessel M. Baudain, "The Continuing 'Misfortune' of Automatism in Early Surrealism," communication +1 , vol. 4, article 10 (2015): 3, accessed February 1, 2017, doi: 10.7275/R5QV3JGQ. 
22 Owen, Enchantment, 6.

23 Rachel Leah Thompson, "The Automatic Hand; Spiritualism, Psychoanalysis, Surrealism," Invisible Culture: An Electronic Journal for Visual Culture 7 (2004): 3, accessed February 1, 2017, http://www. rochester.edu/in_visible_culture/ivchome.html.

24 McKee, Dead, 22.

25 Georges Bataille, "Surrealism," (1948) in The Absence of Myth: Writings on Surrealism, by George Bataille, trans. M. Richardson (London: Verso Books, 2006), 55.

26 Goodrich-Clarke, Western, 179.

27 James Webb, The Occult Underground (Chicago: Open Court, 1990).

28 See Ernst Vegelin van Claerbergen and Barnaby Wright, eds., Georgiana Houghton: Spirit Drawings (London: The Courtauld Gallery, 2016).

29 See Marco Pasi, "The Hidden Hand," in: Tate Etc., issue 37 (2016), accessed March 2, 2017, http://www.tate.org. uk/context-comment/articles/hidden-hand.

30 For more on Spare's sigilisation techniques see, for example, Kasper Opstrup, "By This, That," in: The Fenris Wolf, issue no. 8, ed. Carl Abrahamsson (Stockholm: Trapart Books, 2016), 367-370.

31 See, for example, Phil Baker, Austin Osman Spare: The Life and Legend of London's Lost Artist (London: Strange Attractor Press, 2011), and William Wallace, The Catalpa Monographs: A Critical Survey of Austin Osman Spare (London: Jerusalem Press, 2015).

32 Austin Osman Spare, The Book of Pleasure (self-love): The Psychology of Ecstacy (London: Jerusalem Press, 2011), 41.

33 Breton, "Manifesto," 40.

34 André Breton, "Speech to the Congress of Writers," in: Manifestoes of Surrealism, by André Breton, trans. R. Seaver and H. R. Lane (Ann Arbor: University of Nebraska Press, 2010), 241.

35 Georges Bataille, "The Surrealist Religion," in: The Absence of Myth: Writings on Surrealism, by Georges Bataille, trans. M. Richardson (London: Verso Books, 2006), 76.

36 André Breton, "Prolegomena to a Third Surrealist Manifesto or Not," in: Manifestoes of Surrealism, by André Breton, trans. R. Seaver and H. R. Lane (Ann Arbor: University of Michigan Press, 2010), 287.

37 Aragon, Wave, 7.

38 Pierre Mabille, The Mirror of the Marvelous: The Classic Surrealist Work on Myth, trans. J. Gladding (Rochester: Inner Traditions, 1998), 16.

39 Mabille, Mirror, 33.

40 Aleister Crowley, "Magick in Theory and Practice," in: Magick - Liber ABA - Book Four: Parts I-IV, by Aleister Crowley with M. Desti and L. Waddell (San Francisco: Weiser Books, 2010), 127.

41 Mabille, Mirror, 234; 32.

42 Leonora Carrington, Down Below, trans. Victor Llona (Chicago: Black Swan Press, 1983), 177.

43 See, for example, Michael Richardson, Introduction to The Absence of Myth: Writings on Surrealism, by Georges Bataille, trans. M. Richardson (London: Verso Books, 2006), 1-27, and Bataille, "Religion."

44 Stephen Duncombe, Dream - Re-imaging Progressive Politics in an Age of Fantasy (New York: The New Press, 2007), 89.
45 Theodor Adorno, "Theses on Occultism," in: Minima Moralia: Reflections From Damaged Life, by Theodor Adorno, trans. E. F. N. Jephcott (London: Verso Books, 2005), 239.

46 Adorno, "Occultism," 240.

47 Lars Bang Larsen and Marco Pasi, "Spectres of Art," in: Georgiana Houghton: Spirit Drawings, ed. Ernst Vegelin van Claerbergen and Barnaby Wright (London: The Courtauld Gallery, 2016), 32.

48 Breton, “Manifesto," 33. 